\title{
Potensi dan Respon Masyarakat pada Pengolahan Kulit Kakao Menjadi Krupuk di Desa Sidomakmur Kecamatan Belitang Kabupaten OKU Timur
}

\author{
Ary Eko Prastya Putra, Yesi Destiara \\ Sekolah Tinggi Ilmu Pertanian Belitang \\ Jln.Kampus Pertanian No.3 Belitang Kab.OKU Timur Prov.Sumatera Selatan \\ e-mail: ary.speed88@gmail.com yesidestiara5@gmail.com
}

\begin{abstract}
ABSTRAK
Tujuan dari penelitian ini adalah untuk: 1) mengetahui besarnya potensi pendapatan dari pengolaha kulit kakao menjadi Krupuk di Desa Sido Makmur Kecamatan Belitang Kabupaten OKU Timur, 2) mengetahui respon masyarakat dan konsumen pada pengolahan kulit kakao menjadi Krupuk di Desa Sido Makmur Kecamatan Belitang Kabupaten OKU Timur, 3) mengetahui keputusan konsumen dalam membeli kerupuk kulit kakao di Desa Sido Makmur Kecamatan Belitang Kabupaten OKU Timur. Hasil penelitian menunjukkan bahwa potensi pendapatan yang diperoleh dari pengelolahan kerupuk kulit kakao di Desa Sido Makmur sebesar Rp 5.679.860 /bulan atau Rp 946.643 /PP. Respon masyarakat terhdap pemhelolahan limbah kakao menjadi kerupuk adalah setuju dengan indeks 77,5\% dan respon konsumen terhadap produk kerupuk kulit kakao dapat diklasifikasikan baik. Baik secara bersama - sama maupun secara individu bahwa variabel rasa (X1), kemasan (X2), dan harga (X3) berpengaruh secara signifikan terhadap keputusan konsumen untuk membeli kerupuk kulit kakao.
\end{abstract}

Kata Kunci : Value-added, Kakao, Kelayakan Bisnis.

\section{PENDAHULUAN}

\section{A. Latar Belakang}

Kakao (Thebroma cacao L) atau cokelat merupakan salah satu komoditas andalan perkebunan yang peranannya cukup penting bagi perekonomian nasional, khususnya sebagai penyedia lapangan kerja, sumber pendapatan, dan devisa negara. Potensi besar buah kakao adalah semua komponen dari buah kakao dapat diolah menjadi berbagai produk yang bermanfaat bagi kehidupan manusia dan bernilai ekonomi.

Buah kakao terdiri dari kulit basah, pulp, keping biji dan plasenta. Kulit buah (pod) kakao adalah bagian mesokarp atau bagian dinding buah kakao yang mencakup kulit terluar sampai daging buah sebelum kumpulan biji. Kulit buah kakao merupakan bagian terbesar dari buah kakao. Buah kakao segar terdiri dari $75,52 \%$ kulit buah, 2,20\% plasenta dan $22,28 \%$ biji (Djatmiko, et all, 1989)

Kulit buah (pod) kakao adalah bagian mesokarp atau bagian dinding buah kakao, yang mencakup kulit terluar sampai daging buah sebelum kumpulan biji. Kulit buah kakao merupakan bagian terbesar dari buah kakao (75,52\% dari buah kakao segar). Setiap tahun produksi biji kakao meningkat, ini mengakibatkan semakin meningkatnya kulit buah kakao yang terbuang (Pusat Penelitian Kopi dan Kakao).

Adapun manfaat kulit buah kakao adalah mengobati kanker, menurunkan tekanan darah, menyehatkan jantung, menurunkan kadar kolestrol, anti obesitas, mengobat stress, mengobati diare. Karena kulit kakao terdapat terkandung berbagai senyawa kimia yaitu kadar air 12,96\%, abu 11,10\%, lemak $1,11 \%$, protein $8,75 \%$, karbohidrat $16,27 \%$, lignin $20,11 \%$, selulosa $31,25 \%$ dan Hemiselulosa 48,64\% (Ashadi, 1988).
Di Kecamatan Belitang Kabupaten OKU Timur khususnya Desa Sidomakmur pada umumnya masyarakat setempat memiliki tanaman kakao baik sebagai tanaman tumbuhan maupun sebagai tanaman utama. Sebagian besar penduduk yang memiliki kopi hanya menjual biji dan tidak memanfaatkan kulit buah hingga menjadi limbah. Padahal dengan kandungan yang ada dalamnya, kulit kakao bisa dimanfaatkan dan olahan menjadi sebuah produk yang memiliki nilai jual sehingga bisa untuk menambah pendapatan keluarga serta mengurangi limbah kulit kakao di Desa Sido Makmur.

Limbah kulit kakao merupakan limbah yang sulit diatasi dimana sering berdampak membuat kerugian dari pada keuntungan, salah satu manfaat limbah kulit kakao bisa diolah menjadi sebuah produk yang memiliki nilai jual yaitu dengan mengelolahnya menjadi sebuah kerupuk kulit kakao.

Kerupuk adalah makanan ringan yang tergolong makanan crackers, yaitu makanan yang bersifat kering, renyah, dan kandungan lemak tinggi. Renyah adalah keras dan mudah patah. Produk ini banyak disukai karena rasanya enak, renyah, tahan lama, mudah dibawa dan disimpan, serta dapat dinikmati kapan saja terutama saat santai sambil membaca maupun dinikmati sebagai lauk. (Sulistyowati, 1999).

Kerupuk juga merupakan makanan ringan yang dibuat dari adonan tepung dan dicampur bahan perasa seperti kulit kakao yang di kukus lalu ditumbuk hinga halus sehingga berbentuk dan dijemur.

Desa Sidomakmur adalah salah satu Desa di Kecamatan Belitang Kabupaten OKU Timur yang salh satu petani memanfaatkan limbah kulit kakao menjadi beraneka macam olahan makanan seperti krupuk kulit kakao. 


\section{B. Rumusan Masalah}

Berdasarkan latar belakang dan uraian di atas, adapun permasalahan yang menarik untuk diteliti adalah sebagai berikut :

1. Berapa besar potensi pendapatan yang diperoleh dari pengolahan kulit kakao menjadi krupuk di Desa Sidomakmur Kecamatan Belitang Kabupaten OKU Timur.

2. Bagaimana respon masyarakat dan konsumen pada pengolahan kulit kakao menjadi Krupuk di Desa Sido Makmur Kecamatan Belitang Kabupaten OKU Timur.

3. Bagaimana keputusan konsumen dalam pembelian kerupuk kulit kakao di Desa Sido Makmur Kecamatan Belitang Kabupaten OKU Timur.

\section{Tujuan dan Kegunaan}

Berdasarkan latar belakang dan rumusan masalah di atas, maka tujuan penelitian ini adalah untuk :

1. Mengetahui besarnya potensi pendapatan dari pengolaha kulit kakao menjadi Krupuk di Desa Sido Makmur Kecamatan Belitang Kabupaten OKU Timur.

2. Mengetahui respon masyarakat dan konsumen pada pengolahan kulit kakao menjadi Krupuk di Desa Sido Makmur Kecamatan Belitang Kabupaten OKU Timur.

3. Mengetahui keputusan konsumen dalam membeli kerupuk kulit kakao di Desa Sido Makmur Kecamatan Belitang Kabupaten OKU Timur.

Hasil penelitian ini diharapkan menjadi bahan informasi dan manfaat bagi pihak-pihak berkepentingan dalam meningkatkan pendapatan khususnya dalam usaha krupuk kulit kakao di Desa Sidomakmur Kecamatan Belitang Kabupaten OKU Timur.

\section{KERANGKA PEMIKIRAN}

\section{A. Model Pendekatan}

Kakao merupakan salah satu komoditas unggulan di Indonesia. Kulit buah kakao merupakan limbah utama dari pengolahan biji kakao yaitu mencapai $70 \%$ dari keseluruhan buah, mengandung air sekitar $85 \%$, serat kasar $27 \%$, dan protein $8 \%$, ada juga yang menyebutkan bahwa setiap ton biji kakao kering menghasilkan hasil ikutan 10 ton kulit buah kakao segar. Buah segar yang dihasilkan limbah kulit buah Kakao sebesar $75 \%$. Kandungan hara mineral kulit buah kakao cukup tinggi, khususnya hara Kalium dan Nitrogen. Dilaporkan bahwa $61 \%$ dari total nutrien buah kakao disimpan di dalam kulit buah. (Purnama, 2004).

Selain buahnya yang memiliki manfaat sebagai antidepresan, antikanker dan antioksidan, kulit buah kakao juga memiliki manfaat sebagai antioksidan karena mengandung theobromin sekitar $0,4 \% \mathrm{~b} / \mathrm{b}$ dan kalium 3-4\% b/b dalam bahan kering, campuran dari flavonoid yang terpolimerasi atau terkondensasi meliputi antosianidin, katekin, leukoantosianidin yang kadang berikatan dengan glukosa, monosakarida dan polisakarida yang meliputi pektin, gom, dan selulosa (Listyannisa, 2012).

Komponen utama dari buah kakao adalah kulit buah, plasenta, dan biji. Kulit buah merupakan komponen terbesar dari buah kakao, yaitu lebih dari $70 \%$ berat buah masak. Persentase biji kakao di dalam buah hanya sekitar 27-29\%, sedangkan sisanya adalah plasenta yang merupakan pengikat dari 30 sampai 40 biji. Kulit buah kakao segar mengandung kadar air yang tinggi sehingga mudah menjadi busuk. Buah kakao menghasilkan $74 \%$ kulit buah, $24 \%$ biji dan $2 \%$ plasenta. (Nasrullah dan Ella, 1993).

Semua komponen dari buah kakao dapat diolah menjadi berbagai produk yang bermanfaat bagi kehidupan manusia dan bernilai ekonomi. Komponen buah kakao segar terdiri dari 3 bagian yaitu kulit buah sekitar 74-75,67\%, biji 21,74 - 24\% dan placenta 2 2,59\% (Haryati dan Mardjosuwito, 1984)

Kulit buah kakao memiliki kandungan gizi diantaranya kadar air 12,96\%, abu $11,10 \%$, lemak $1,11 \%$, protein $8,75 \%$, karbohidrat $16,27 \%$, lignin $20,11 \%$, selulosa $31,25 \%$ dan hemiselulosa $48,64 \%$ (Ashadi, 1988).

Arahan konseptual dan asumsi-asumsi yang terkandung dalam uraian di atas memungkinkan tersususunnya suatu kerangka berfikir argumentatif berupa model pendekatan, bagan alir pada gambar berikut :

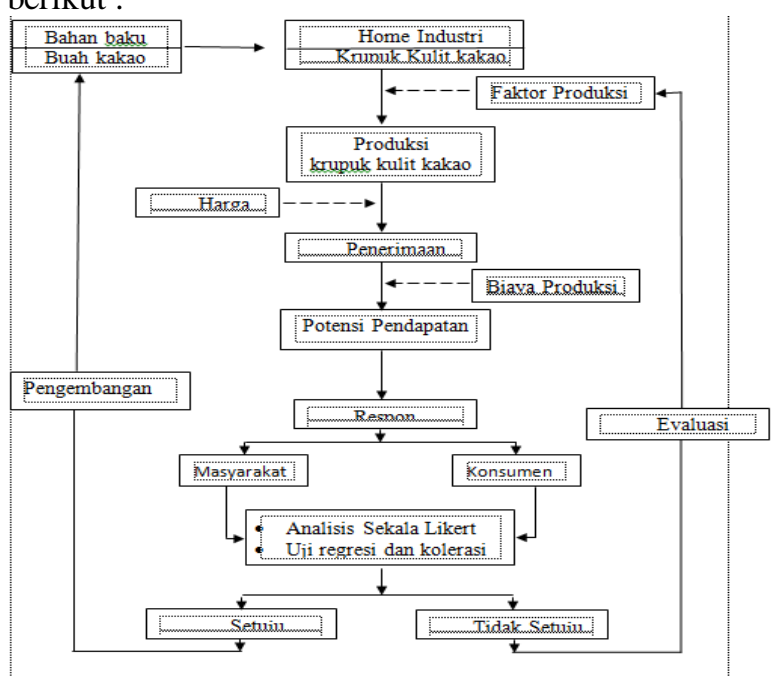

Keterangan :

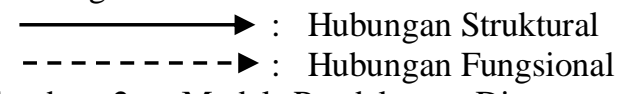

Gambar 2. Model Pendekatan Diagramatis Usaha Pengolahan Kulit Kakao Menjadi Krupuk di Desa Sidomakmur Kecamatan Belitang Kabupaten OKU Timur.

\section{B. Hipotesis}

Berdasarkan latar belakang, kerangka pemikiran dan uraian di atas maka hipotesis yang diajukan dalam penelitian ini adalah :

1. Bahwa terdapat potensi pendapatan pada pengelolahan limbah kakao menjadi kerupuk di 
Desa Sidomakmur Kecamatan Belitang Kabupaten OKU Timur.

2. Bahwa respon masyarakat dan konsumen pada pengelolahan limbah kulit kaako menjadi kerupuk di Desa Belitang Sidomakmur adalah baik / setuju.

3. Bahwa keputusan konsumen dalam pembelian kerupuk kulit kakao di Desa Sido Makmur berhubungan dan dipengaruhi oleh rasa, kemasan dan harga.

\section{Batasan-Batasan}

Batasan yang akan digunakan dalam penelitian ini adalah sebagai berikut :

1. Responden adalah pelaku home industri krupuk kulit kakao, konsumen serta petani yang memiliki kakao di desa Sidomakmur Kecamatan Belitang Kabupaten OKU Timur.

2. Kulit kakao adalah bahan baku utama yang digunakan untuk pengolahan krupuk kulit kakao.

3. Krupuk kulit kakao adalah makanan ringan yang dibuat dari adonan tepung dan dicampur bahan perasa seperti kulit kakao yang di kukus lalu ditumbuk hinga halus sehingga berbentuk dan dijemur lalu digoreng. Bisa untuk cemilan maupun dimakan sebagai lauk wajib atau tambahan.

4. Biaya tetap adalah biaya yang penggunaanya tidak habis dalam sekali proses produksi dan biaya yang besar kecilnya tidak mempengaruhi hasil produksi.

5. Biaya variabel adalah biaya yang jumlahnya tergantung dari besarnya jumlah produksi serta habis dalam satu kali proses produksi.

6. Biaya produksi adalah total biaya yang dikeluarkan dalam satu kali proses produksi yang meliputi biaya tetap dan biaya variabel.

7. Produksi adalah produk yang dihasilkan responden berupa krupuk kulit kakao.

8. Harga adalah nilai jual dari krupuk kulit kakao yang ditetapkan oleh responden pada saat penelitian (Rp/kemasan).

9. Penerimaan adalah jumlah hasil dari produksi $(\mathrm{kg})$ yang diperoleh home industri dikali dengan harga (Rp), pada saat penelitian.

10. Pendapatan adalah selisih antara penerimaan dengan biaya produksi yang dikeluarkan selama proses produksi berlangsung.

11. Skala Likert adalah tolak ukur untuk mengetahui respon masyarakat dan konsumen terhadap pengolahan kulit kakao menjadi krupuk.

12. Konsumen adalah orang yang membeli dan merasakan krupuk kulit kakao.

13. Masyarakat adalah warga di desa sidomakmur yang memiliki tanaman kakao

14. Respon adalah tanggapan masyarakat terhadap krupuk kulit kakao.

\section{PELAKSANAAN PENELITIAN}

\section{A. Tempat dan Waktu}

Penelitian ini dilaksanakan di Desa Sidomakmur Kecamatan Belitang Kabupaten OKU Timur.
Pemilihan lokasi dilakukan dengan sengaja (purposive) dengan mempertimbangkan bahwa di Desa Sidomakmur terdapat home industri pengolahan kulit kakao menjadi krupuk. Penelitian ini telah dilaksanakan bulan Maret 2020.

\section{B. Metode Penelitian dan Penarikan Contoh}

Metode penelitian yang digunakan adalah metode survey, menurut Nazir (2003), metode survei adalah metode penyelidikan untuk memperoleh fakta - fakta dari gejala - gejala yang ada dan mencari keterangan secara faktual, baik tentang institusi sosial ekonomi atau politik dari suatu kelompok ataupun suatu daerah.

Metode penarikan contoh yang digunakan adalah metode proportional simple random sampling. Proportional simple random sampling adalah pengambilan sampel dari populasi secara acak dan berstrata secara proposional. Sampel yang akan dijadikan responden adalah masyarakat yang mempunyai tanaman kakao dan konsumen yang membeli kerupuk kulit kakao. Berdasarkan hasil survey terdapat 52 masyarakat pemilik kakao dan 65 orang dari 3 kios yang membeli kerupuk kulit kakao dalam 1 bulan (sewaktu - waktu bisa berubah).

Penentuan sampel dihitung dengan menggunakan rumus Slovin (Rahmat, 2001) sebagai berikut :

$n=\frac{N}{1+\left(\varepsilon^{2}\right)_{A N}} \Longrightarrow n \frac{117}{1+\left(117^{2}\right)_{1117}}=54$ orang

Dimana :

$\mathrm{n}=$ besaran sampel

$\mathrm{N}=$ besaran populasi

$\mathrm{e}=$ Kesalahan dalam pengambilan sampel di tetapkan sebesar $10 \%$

Berdasarkan hasil perhitungan diperoleh sampel sebanyak 54 orang . untuk memperoleh sampel masing - masing yaitu masyarakat yang memiliki kakao dan konsumen di tentukan dengan teknik pengambilan sampel proporsional dengan rumus sebagai berikut :

$$
\begin{aligned}
n_{1}=\left[\frac{N i}{N}\right] n \rightleftharpoons n_{1} & =\left[\frac{52}{117}\right] 54=24 \\
n_{2} & =\left[\frac{65}{117}\right] 54=30
\end{aligned}
$$

Keterangan

$\mathrm{n}_{1}=$ jumlah sampel masyarakat pemilik kakao

$\mathrm{n}_{2}=$ jumlah sampel masyarakat yang membeli kerupuk (konsumen)

$\mathrm{Ni}=$ jumlah populasi masing - masing

$\mathrm{N}=$ jumlah seluruh populasi

Secara jelas jumlah responden yang diambil dalam penelitian ini dapat dilihat pada tabel 1 sebagai berikut :

Tabel 1. Jumlah Responden Penelitian.

\begin{tabular}{cccc}
\hline No & Responden & Populasi & Sampel \\
\hline 1 & Respon Masyarakat & 52 & 24 \\
2 & Respon Konsumen & 65 & 30 \\
\hline & & 117 & 54 \\
\hline
\end{tabular}

Sumber : Hasil Data Olahan Primer, 2020. 


\section{Metode Pengumpulan Data}

Data yang dikumpulkan dalam penelitian ini adalah data primer dan data sekunder. Data primer adalah data yang diperoleh secara langsung dari sumburnya, diamati dan dicatat oleh peneliti. Data primer diperoleh melalui observasi atau pengamatan dan wawancara langsung berdasarkan daftar quisioner yang sudah disiapkan, sedangkan data sekunder merupakan data yang diperoleh dari lembaga-lembaga yang ada hubungannya dengan penelitian.

\section{Metode Pengolahan Data}

a. Untuk menjawab tujuan penelitian yang pertama yaitu untuk menghitung besarnya potensi pendapatan pada pengolahan kulit kakao menjadi krupuk di Desa Sidomakmur Kecamatan Belitang Kabupaten OKU Timur dihitung dengan menggunakan rumus sebagai berikut :

1). Untuk menghitung biaya produksi digunakan rumus (Suratiyah, 2015):

$\mathrm{TC}=\mathrm{FC}+\mathrm{VC}$

Dimana :

$\mathrm{TC}=$ Total Cost $/$ Biaya Total

$\mathrm{FC}=$ Fixed Cost/Biaya Tetap

$\mathrm{VC}=$ Variable cost/Biaya Variabel

2). Untuk menghitung penerimaan digunakan rumus (Suratiyah, 2015) :

$\mathrm{TR}=\mathrm{P} \times \mathrm{Y}$

Dimana :

$\mathrm{TR}=$ Total Revenues $/$ Penerimaan

$\mathrm{P}=$ Price $/$ Harga

$\mathrm{Y}=$ Yeild/Jumlah Produksi

3). Untuk menghitung pendapatan menggunakan rumus(Suratiyah, 2015) :

$\mathrm{I}=\mathrm{TR}-\mathrm{TC}$

Dimana :

$\mathrm{I}=$ Income/Pendapatan

$\mathrm{TR}=$ Total Revenue $/$ Penerimaan

$\mathrm{TC}=$ Total Cost $/$ Total Biaya Produksi

b. Untuk menjawab tujuan penelitian yang kedua yaitu respon masyarakat pada pengolahan kulit kakao menjadi krupuk menggunakan sekala likert sebagai berukut (Darmadi, 2011) :

1). Untuk mengetahui besarnya jumlah sekor dapat dihitung dengan rumus :

Jumlah sekor $=\mathrm{T} \times \mathrm{Pn}$

Dimana :

$\mathrm{T}=$ Total Jumlah panelis yang memilih

Pn $=$ Pilihan angka Skor Likert

2). Untuk mendapatkan hasil interpretasi, harus diketahui dulu skor tertinggi (X) dan skor terendah (Y) untuk item penilaian dengan rumus sebagai berikut :

Index $(\%)==\frac{\text { total ghor }}{F} \times 100$

Dimana :

$\mathrm{Y}=$ Skor tertinggi likert $\mathrm{x}$ jumlah panelis

$\mathrm{X}=$ Skor terendah likert $\mathrm{x}$ jumlah panelis

3). Sebelum menyelesaikannya kita harus mengetahui interval (jarak) dan interpretasi persen agar mengetahui penilaian dengan metode mencari inverval sekor persen (I) dengan rumus sebagai berikut :

Interval $=\frac{100}{\text { jumiah skoy }}=\frac{100}{5}=20$

(Ini adalah intervalnya jarak dari terendah $0 \%$ hingga tertinggi 100\%). Berikut kriteria interpretasi skornya berdasarkan interval :

Tabel 2. Interval Interpretasi Sekor Likert

\begin{tabular}{cll}
\hline No & \multicolumn{1}{c}{ Index } & \multicolumn{1}{c}{ Keterangan } \\
\hline 1 & $0 \%-19,99 \%$ & Sangat tidak setuju \\
2 & $20 \%-39-99 \%$ & Tidak setuju \\
3 & $40 \%-59-99 \%$ & Netral/ragu-ragu \\
4 & $60 \%-79-99 \%$ & Setuju \\
5 & $80 \%-100 \%$ & Sangat setuju \\
\hline
\end{tabular}

c. Sedangkan untuk menjawab respon konsumen yaitu sama dengan respon masyarakat namun dilanjutkan dengan uji kolerasi dan uji regresi linier berganda guna unuk mengetahui hubungan dan pengeruh antara variabel X dan Variabel Y. Menurut Riduwan, (1997 : 123) untuk pengujian tingkat hubungan instrument dalam penelitian ini dengan mencari nilai kolerasi produk moment ( $\mathrm{r}$ hitung) dengan rumus sebagai berikut :

$r_{x y}=\frac{\left(n \Sigma x_{i} y_{i}-\left(\Sigma x_{i}\right) \cdot\left(\Sigma y_{i}\right)\right.}{\sqrt{\left\{n \Sigma x_{i}^{2}-\left(\Sigma x_{i}\right)^{2}\right\}} \cdot\left\{n \Sigma y_{i}^{2}-\left(\Sigma y_{i}\right)\right\}^{2}}$

Dimana

$\mathrm{r}_{\mathrm{xy}}=$ Koefisien korelasi Product Moment

yi = Nilai skor Total

$\mathrm{xi}=$ Skor item

$\mathrm{n}=$ Jumlah Sampel

Yang kemudian dianalisis dengan menggunakan persamaan linier berganda yaitu dengan menggunakan rumus persamaan sebagai berikut :

Dimana

$\mathrm{Y}=$ variabel terikat (respon konsumen)

$\mathrm{X}=$ variabel bebas

$\mathrm{X}_{1}=$ Rasa

$\mathrm{X}_{2}=$ Kemasan

$X_{3}=$ Harga (Kotler, 1999 dalam Resie 2010)

$\mathrm{a}=$ Konstanta

$\mathrm{b}_{1}=$ Koefisien regresi 1

$\mathrm{b}_{2}=$ Koefisien regresi 2

$\mathrm{b}_{3}=$ Koefisien regresi 3

\section{HASIL DAN PEMBAHASAN}

\section{A. Pengolahan Kerupuk Kulit Kakao}

Kerupuk kulit kakao diolah dengan memanfaatkan limbah kulit kakao yang ada di sekitar lingkungan. Untuk melakukan pengolahan kerupuk kulit kakao diperlukan beberapa bahan baku yaitu berupa kulit kakao, tepung tapioca, tepung terigu, ketumbar, bawang putih, garam dan penyedap rasa. Limbah kulit kakao yang digunakan dalam pengelolahan kerupuk kulit kakao adalah kulit kakao yang diperoleh dari buah kakao yang habis dipetik ataupun kulit yang masih basah dan segar.

Pembuatan kerupuk kulit kakao dalam satu kali proses produksi membutuhkan waktu lima hari mulai dari pembuatan sampai pengemasan, dan ada beberapa tahap yang perlu diperhatikan dalam proses produksi. 
Adapun tahapan dalam proses pengolahan kerupuk kulit kakao adalah sebagai berikut :

\section{a.Persiapan Bahan Baku dan Alat}

Bahan baku dan alat yang perlu disiapkan untuk digunakan dalam pembuatan kerupuk kulit kakao dapat dilihat pada table berikut:

Tabel 3. Kebutuhan bahan untuk membuat kerupuk kulit kakao.

\begin{tabular}{cccc}
\hline No & Uraian & Kebutuhan & Satuan \\
\hline $1 \quad$ Bahan - Bahan : & & \\
Kulit kakao & & \\
Tepung tapioca & & \\
Tepung terigu & & $\mathrm{Kg}$ \\
Ketumbar & 10 & $\mathrm{Kg}$ \\
Bawang putih & 15 & $\mathrm{Kg}$ \\
Garam & 5 & $\mathrm{~kg}$ \\
Penyedap rasa & 0,2 & $\mathrm{Kg}$ \\
Alat - alat : & 0,25 & Bungkus \\
Pisau & 2 & Bungkus \\
Panci & 1 & \\
Baskom & & Unit \\
Alat Pengapit & 2 & Unit \\
& 1 & Unit \\
& & 2 & Unit
\end{tabular}

Sumber : Hasil Data Olahan Primer, 2020.

\section{b. Proses Produksi}

Proses produksi dalam pembuatan kerupuk kulit kakao ini membutuhkan waktu lima hari malai dari pembuatan sampai pengemasan dalam satu proses produksi. Dalam proses produksi pengelolahan kerupuk kulit kakao ada beberapa tahapan yang harus dilakukan diantaranya sebagai berikut:

a). Mengupas kulit kakao ; Limbah kulit kakao yang masih segar, basah dan bagus di bersihkan dan dikupas sampai kulit luar bersih.

b). Pencucian kulit kakao ; kulit kakao yang sudah dikupas di cuci atau dibersihan dengan air mengalir sampai benar - benar bersih atau sampai lendir yang ada pada kulit kakao berkurang.

c). Pengukusan I ; kulit kakao yang sudah di kupas dan dicuci bersih kemudian di kukus selama \pm 1 jam.

d). Pembuatan Adonan ; sambil menunggu kulit kakao yang di kukus, selanjutnya pembuatan adaonan. Pembuatan adonan dilakukan dengan cara mencampurkan semua bahan seperti tepung terigu, tepung tapioca, bawang putih dan ketumbar yang sudah di tumbuk halus dengan garam, lalu masukkan penyedap rasa dalam adonan, bias tambahkan air jika diperlukan (sisihkan).

e). Penumbukan kulit kakao ; kulit kakao yang sudah di kukus selama \pm 1 jam tadi di tumbuk halus bisa menggunakan blender maupun dengan botol. Setelah kulit kakao halus campurkan adonan sampai rata dan adoni sampai biasa dibentuk.

f). Pengukusan II ; setelah kulit kakao selesai diadoni selanjutnya kukus kembali adonan \pm 1 jam. g). Pengirisan Adonan ; adonan yang sudah dikukus diangkat dan dinginkan, setelah dingin di iris tipis tipis dengan menggunakan pisau yang kemudian dijemur. Penjemuran bisa dilakukan selama 1-2 hari tergantung cuaca.

h). Penggorengan ; seetelah kerupuk yang dijemur kering selanjutnya adalah penggorengan. Penggorengan dilakukan dengan menggunakan minyak panas lalu masukkan kerupuk secukupnya, dalam penggorengan api tidak boleh terlalu brsar atau kecil agar tingkat kematangan kerupuk benar benar sempurna.

i). Pengemasan ; kerupuk yang sudah digoreng ditiriskan beberapa menit agar saat pengemasan minyak yang terdapat pada kerupuk tidak banyak. Kemudian kerupuk di kemas dalam plastic ukuran 15 x 30 dan di beri label agar tanpak menarik, tertup rapat dan simpan di tempat yang kering. Pengemasan yang baik akan mempengaruhi mutu produk yang akan dihasilkan dan meningkatkan daya tarik bagi konsumen untuk membeli produk tersebut.

\section{B. Analisis Potensi Usaha Pengolahan Kerupuk Kulit Kakao}

\section{a. Biaya Produksi}

Biaya Produksi adalah semua biaya yang digunakan dalam usaha pengelolahan kerupuk kulit kakao yang meliputi biaya tetap dan biaya variable. Biaya tetap adalah biaya yang besarnya tidak mempengaruhi oleh jumlah produksi, yang meliputi biaya sewa lahan dan biaya penyusutan alat. Sedangkan biaya variable adalah biaya yang besar kecilnya tergantung kepada besar kecilnya produksi dan akan habis dalam satu kali proses produksi. Biaya variable dalam usaha pengelolahan kerupuk kulit kakao meliputi biaya sarana produksi dan biaya tenaga kerja.

Besarnya biaya produksi yang digunakan pada usaha pengelolahan kulit kakao menjadi kerupuk dihitung dengan menggunakan rumus $\mathrm{TC}=\mathrm{FC}+\mathrm{VC}$ adalah $\mathrm{TC}=\mathrm{Rp} 50.743+\mathrm{Rp} 333.625=\mathrm{Rp} 384.368$, untuk lebih jelasnya dapat dilihat pada tabel berikut :

Tabel 4. Biaya Produksi Usaha Pengelolahan Kerupuk Kulit Kakao.

\begin{tabular}{|c|c|c|c|}
\hline No & Uraian & Satuan & Nilai \\
\hline 1 & $\begin{array}{l}\text { Biaya Tetap } \\
\text { Sewa Tempat } \\
\text { Penyusutan Alat }\end{array}$ & $\begin{array}{l}\text { Rp/PP } \\
\text { Rp/PP }\end{array}$ & $\begin{array}{r}48.611 \\
2.132\end{array}$ \\
\hline 2 & $\begin{array}{l}\text { Biaya Variabel } \\
\text { Biaya Saprodi } \\
\text { Biaya Tenaga Kerja }\end{array}$ & $\begin{array}{l}\text { Rp/PP } \\
\text { Rp/PP }\end{array}$ & $\begin{array}{r}255.500 \\
78.125\end{array}$ \\
\hline & Total Biaya Produksi & & 384.368 \\
\hline
\end{tabular}

Sumber : Hasil Data Olahan Primer, 2020.

Berdasrkan tabel diatas diketahui jumlah seluruh biaya produksi yang dikeluarkan oleh 
responden dalam usaha pengelolahan kerupuk kulit kakao dalam satu kali produksi yaitu sebesar $\mathrm{Rp}$ 384.368 yang meliputi biaya sewa tempat sebesar Rp 48.611 /pp biaya penyusutan alat sebesar Rp 2.132 /pp , biaya saprodi sebesar Rp 255.500 /pp, dan biaya tenaga kerja sebesar Rp 78.125/pp

\section{b. Penerimaan dan Pendapatan}

Penerimaan merupakan perkalian antara total produk yang terjual dengan harga persatuan produk. Besarnya penerimaan yang diperoleh dari penjualan kerupuk kulit kakao dihitung dengan menggunakan rumus TR = $\mathrm{P} \times \mathrm{Y}$ adalah sebagai berikut TR $=\mathrm{Rp} 3.500 \times 200=$ 700.000, untuk lebih jelasnya mengenai penerimaan yang diperoleh dari pengelolahan kerupuk kulit kakao dapat dilihat pada tabel berikut :

Tabel 5. Penerimaan Pengolahan Kulit Kakao menjadi Kerupuk.

\begin{tabular}{ccccccc}
\hline $\begin{array}{c}\text { N } \\
\text { o }\end{array}$ & Uraian & Produksi & Satuan & $\begin{array}{c}\text { Hasil } \\
\mathbf{( 0 , 1 / b u} \\
\text { ngkus) }\end{array}$ & $\begin{array}{c}\text { Harga } \\
(/ \text { /bungku } \\
\text { s) }\end{array}$ & Jumlah \\
\hline 1 & $\begin{array}{l}\text { Kerupuk } \\
\text { Kulit } \\
\text { Kakao }\end{array}$ & 10 & $\mathrm{Kg}$ & 200 & 3.500 & 700.000 \\
\hline
\end{tabular}

Sumber : Hasil Data Olahan Primer, 2020.

Pada tabel diatas menunjukkan bahwa produksi pengelolahan kerupuk kulit kakao dalam satu kali proses produksi yaitu $10 \mathrm{~kg}$ dan menghasilakan 200 bungkus, dengan harga jual sebesar Rp 3.500 / bungkus. Dengan begitu akan diterima penerimaan sebesar $\mathrm{Rp}$ 700.000 / PP.

Sedangkan pendapatan adalah hasil pengurangan antara hasil penjualan dengan semua biaya dikeluarkan sampai produk tersebut berada ditangan konsumen. Besarnya pendapatan yang diperoleh dari usaha pengolahan kerupuk kulit kakao dapat dihitung dengan menggunakan rumus I = TR TC yaitu sebagai berikut I = Rp 700.000 - Rp 384.368 $=\operatorname{Rp} 315.632$, untuk lebih jelasnya dapat dilihat pada tabel sebagai berikut :

Tabel 6. Pendapatan dari Pengelolahan Kerupuk Kulit Kakao.

\begin{tabular}{ccccc}
\hline No & Uraian & $\begin{array}{c}\text { Penerimaan } \\
(\mathbf{R p} / \mathbf{P P})\end{array}$ & $\begin{array}{c}\text { Biaya } \\
\text { Produksi } \\
(\mathbf{R p} / \mathbf{P P})\end{array}$ & $\begin{array}{c}\text { Pendapatan } \\
(\mathbf{R p} / \mathbf{P P})\end{array}$ \\
\hline & & & & \\
1 & $\begin{array}{l}\text { Kerupuk Kulit } \\
\text { Kakao }\end{array}$ & 700.000 & 384.368 & 315.632 \\
\hline
\end{tabular}

Sumber : Hasil Data Olahan Primer, 2020.

Dari tabel diatas diketahui penerimaan dalam satu kali proses produksi sebesar Rp 700.000, dan biaya yang dikeluarkan dalam satu kali proses Produksi sebesar Rp 384.368 /pp . Sehingga diperoleh Pendapatan sebesar Rp 315.632 /PP.

\section{c. Potensi Pendapatan Limbah Kakao}

Limbah kakao adalah limbah yang dihasilkan dari buah kakao yang masak dan sudah di ambil bijinya dan tidak dimanfaatkan lagi. Limbah kulit kakao ini jika diolah menjadi sesuatu yang bermanfaat misalnya diolah menjadi sebuah cemilan yaitu kerupuk maka limbah tersebut akan memiliki nilai jual.

Sebelumnya sudah diketahui potensi pendapatan dari pengelolahan limbah kakao menjadi kerupuk dalam satu kali proses produksi yaitu sebesar Rp 315.632. Di Desa Sidomakmur masyarakatnya banyak yang memiliki tanaman kakao dan limbahnya tidak dimanfaatkan, namun jika limbah tersebut dimanfaatkan untuk diolah menjadi kerupuk kulit kakao maka memiliki potensi pendapatan karena dalam satu batang tanaman kakao memiliki potensi menghasilkan buah sebanyak 135 - 200 buah dan dari 24 responden mempunyai tanaman kakao sebanyak 25 -100 batang, maka potensi produksi kerupuk kulit kakao yang di hasilkan mencapai $531-1.875 \mathrm{~kg}$ atau 10.625 - 37.500 bungkus Dengan harga jual Rp 3.500 Maka diperoleh penerimaan sebesar Rp 37.187.500 131.250.000 dan memiliki potensi pendapatan sebesar Rp 16.767.844 - 59.180.625 dalam satu kali musim panen ( 5 bulan) dengan rata - rata Rp 5.679.860/bulan atau Rp 946.643 dalam satu kali proses produksi.

\section{Respon Masyarakat}

Menurut Sobur, (2003), respon adalah suatu tingkah laku atau sikap yang berwujud baik sebelum pemahaman yang mendetail, penelitian, pengeruh atau penolakan, suka atau tidak suka serta pemanfaatan pada suatu fenomena tertentu.

\section{a. Respon Masyarakat yang Memiliki Kakao}

Respon yang diberikan masyartakat yang memiliki kakao dengan adanya pengelolahan kulit kakao menjadi kerupuk di Sido Makmur, dilakukan dengan menggunakan analisis sekala likert, untuk lebih jelasnya dapat dilihat pada tabel sebagai berikut :

Tabel 7. Respon Masyarakat terhadap Pengolahan Kerupuk Kulit Kakao.

\begin{tabular}{clcr}
\hline No & Pernyataan & Skor Likert & Persentase \% \\
\hline 1 & Sangat Tidak Setuju & 0 & 0 \\
2 & Tidak Setuju & 2 & 8,33 \\
3 & Netral & 3 & 12,5 \\
4 & Setuju & 15 & 62,50 \\
5 & Sangat Setuju & 4 & 16,67 \\
\hline \multicolumn{2}{c}{ Jumlah } & 24 & 100 \\
& Indeks & \multicolumn{2}{c}{$77,50 \%$ (Setuju) } \\
\hline
\end{tabular}

Sumber : Hasil Data Olahan Primer, 2020.

Berdasarkan hasil wawancara dilapangan dengan menggunakan kuisioner terhadap 24 responden, respon masyarkat pemilik kakao terhadap pengelolahan kerupuk kulit kakao, ditunjukan pada tabel diatas yaitu $16,67 \%$ masyarakat sangat setuju, 62,50\% masyarakat setuju dengan adanya pengelolahan kerupuk kulit kakao, namun $12,50 \%$ netral / ragu-ragu serta $8,33 \%$ masrakat tidak setuju dengan pengolahan kerupuk kulit kakao

Masrakat yang setuju terhadap pengelolahan limbah kakao menjadi kerupuk adalah masyarakat yang bekerja di sawah dan tidak ada kegiatan lain selain sawah hal ini dikarenakan mereka tidak ada kegiatan selain pada musim tanam dan panen, mereka juga rata 
- rata berpendidikan SD - SMP dan masih umur produktif yaitu antara $30-45$ tahun. Sedangkan masyarakat yang tidak setuju adalah masyarakat yang bekerja sebagai pegawai maupun wirasuasta dikarenakan mereka sibuk dengan pekerjaan mereka sehingga tidak ada waktu untuk mengelolahnya.

\section{b. Respon Konsumen}

Respon yang diberikan masyarakat yang membeli kerupuk kulit kakao untuk memberikan penilaian terhadap produk kerupuk kulit kakao yang dinilai dari segi rasa yang enak, kemasan yang menarik dan harga yang terjangkau, yang kemudian diputuskan dengan loyabilitas atau kepuasan konsumen terhadap produk tersebut.

\section{Rasa Kerupuk Kulit Kakao}

Rasa adalah sesuatu yang setelah dikecap oleh lidah dan ditanggapi oleh perasaan (Kamus Bahasa Indonesia, 1998). Rasa yang diberikan pada kerupuk ini adalah rasa gurih dan pedas gurih. Rasa yang dinikmati konsumen akan dinilai berdasrkan klasifikasi berikut : sangat suka (5), suka (4), cukup suka (3), tidak suka (2) dan sangat tidak suka (1). Berdasarkan hasil penelitian dengan pemabagian kuesioner kepada 30 konsumen diketahui respon konsumen terhadap rasa kerupuk kakao dapat dilihat pada tabel berikut : Tabel 8. Respon Konsumen terhadap Rasa.

\begin{tabular}{|c|c|c|c|}
\hline No & Pernyataan & Jumlah & Persentase \% \\
\hline 1 & Sangat Tidak Suka & 0 & 0 \\
\hline 2 & Tidak Suka & 0 & 0 \\
\hline 3 & Cukup Suka & 4 & 13,33 \\
\hline 4 & Suka & 17 & 56,67 \\
\hline 5 & Sngat Suka & 9 & 30 \\
\hline & Jumlah & 30 & 100 \\
\hline & Indeks & \multicolumn{2}{|c|}{$\mathbf{8 3 , 3 3 \%}$ (Sangat Suka) } \\
\hline
\end{tabular}

Sumber : Hasil Data Olahan Primer, 2020.

Pada tabel diatas diketahui $30 \%$ atau 9 orang konsumen sangat suka terhadap rasa kerupuk kulit kakao, 56,67\% atau 17 orang konsumen suka terhadap kerupuk kulit kakao namun $13,33 \%$ atau 4 orang consume cukup suka terhadap kerupuk ini. Sehingga dapat disimpulkan terdapat indeks 83,33\% dengan arti konsumen sangat suka pada rasa kerupuk kulit kakao dan rata - rata yang suka kerupuk kulit kakao ini adalah ibu - ibu dan Remaja.

\section{Kemasan Kerupuk Kulit Kakao}

Kemasan kerupuk kulit kakao yang merupakan pembungkus kerupuk kulit kakao pada saat terjadi proses pembelian, yang terbuat dari plastic yang bertujuan agar terlihat lebih rapi dan dapat menarik perhatian konsumen. Kemasan kerupuk kulit kakao dinilai berdasarkan klasifikasi berikut : sngat menarik (5), menarik (4), cukup menarik (3), tidak menarik (2) dan sangat tidak menarik (1). Berdasarkan hasil penelitian dengan pembangian kuesioner kepada konsumen yaitu banyak konsumen yang menyatakan bahwa kemasan pada kerupuk kulit kakao ini menarik, untuk lebih jelas dapat dilihat pada tabel berikut. Tabel 9. Respon Konsumen terhadap Kemasan.

\begin{tabular}{llll}
\hline No & Pernyataan & Jumlah & Persentase \% \\
\hline
\end{tabular}

\begin{tabular}{|c|c|c|c|}
\hline 1 & Sangat Tidak Menarik & 0 & 0 \\
\hline 2 & Tidak Menarik & 2 & 6,67 \\
\hline 3 & Cukup Menarik & 7 & 23,33 \\
\hline 4 & Menarik & 14 & 46,67 \\
\hline 5 & Sangat Menarik & 7 & 23,33 \\
\hline & Jumlah & 30 & 100 \\
\hline & Indeks & \multicolumn{2}{|c|}{ 67,50\% (Menarik) } \\
\hline
\end{tabular}

Sumber : Hasil Data Olahan Primer, 2020.

Berdasarkan data diatas diketahui bahwa mayoritas responden yaitu konsumen yang mengkonsumsi kerupuk kulit kakao termasuk dalam klasifikasi menarik terhadap kerupuk kulit kakao yaitu dengan indeks $67,5 \%$. Dengan sebaran yang dibagi pada responden diketahui dari table diatas yaitu 23,33\% konsumen menjawab kemasan kerupuk kulit kakao ini sangat menarik, 46,67\% konsumen menjawab menarik namun 23,33\% konsumen menjawab cukup menarik bahkan ada $6,67 \%$ konsumen yang mengatakan bahwa kemasan kerupuk kulit kakao ini tidak menarik.

Hal ini disebabkan karena berdasarkan keadaan dilapangan saat terjadi proses pembelian terdapat sebagian dari responden lebih memilik dan membeli kerupuk dengan kemasan yang bermerek / berlebel, sebab kemasan yang bermerk lebih rapid an bersih sehingga mempunyai daya tarik jika dilihat.

\section{Harga Kerupuk Kulit Kakao}

Harga kerupuk kulit kakao ditetapkan sebagai pandangan konsumen terhadap kesesuan harga kerupuk yang dipasrkan. Berdasarkan hasil penelitian harga kerupuk kulit kakao yang diberikan di klasifikasikan sebagai berikut : sangat terjangkau (5), terjangkau (4), cukup terjangkau (3), tidak terjaungkau (2) dan sangat tidak terjangkau (1). Dan hasil yang diperoleh dari penelitian dengan pembangian kuesioner diketahui ternyata harga yang diberikan terjangkau. Untuk lebih jelas dapat dilihat pada tabel berikut :

Tabel 10. Respon Konsumen terhadap Harga Kerupuk Kulit Kakao.

\begin{tabular}{clrr}
\hline No & \multicolumn{1}{c}{ Pernyataan } & Jumlah & Persentase \% \\
\hline 1 & Sangat Tidak Terjangkau & 0 & 0 \\
2 & Tidak Terjangkau & 0 & 0 \\
3 & Cukup Terjangkau & 6 & 20 \\
4 & Terjangkau & 14 & 46,67 \\
5 & Sangat Terjangkau & 10 & 33,33 \\
\hline & Jumlah & $\mathbf{3 2}$ & $\mathbf{1 0 0}$ \\
& Indeks & $\mathbf{6 7 , 5 0 \%}$ (Terjangkau) \\
\hline
\end{tabular}

Sumber : Hasil Data Olahan Primer, 2020.

Harga yang dipasarkan di warung yang ada di Desa Sidomakmur masuk dalam klasifikasi harganya terjangkau yaitu dengan ideks 67,5\%. Sebaran responden terhadap harga di table diatas diketahui yaitu sebesar 33,33\% konsumen sangat setuju dengan harga yang diberikan untuk membeli kerupuk kulit kakao ini, 46,67\% setuju tetapi ada $20 \%$ menjawab netral. 
Hal ini dikarenakan harga yang ditawarkan untuk membeli kerupuk sesuai dengan produknya yaitu harga kerupuk yang kemasan kecil (100g) Rp 5.000 dan yang kemsan besar (200g) Rp 10.000, harga tersebut bisa berubah kapan saja, tergantung pada produsen yang memasarkannya. Dari hasil pengamatan di lapangan mayoritas responden menganggap bahwa harga yang dipasarkan sudah terjangkau dan telah sesuai dengan kemampuan beli tiap responden.

\section{Kepuasan Konsumen}

Kepuasan konsumen merupakan fungsi dari seberapa dekat harapan pembeli atas suatu produk dengan apa yang dirasakan pada produk tersebut (Sumarwan, 2004). Berdasrkan hasil penelitian kepuasan Diklasifikasikan sebagai berikut : sangat puas (5), puas (4), cukup puas (3), tidak puas (2), dan sangat tidak puas (1). Sebaran konsumen berdasarkan kepuasan dapat dilihat pada tabel berikut:

Tabel 11. Respon terhadap Kepuasan Konsumen.

\begin{tabular}{|c|c|c|c|}
\hline No & Pernyataan & Jumlah & Persentase \% \\
\hline 1 & Sangat Tidak Puas & 0 & 0 \\
\hline 2 & Tidak Puas & 0 & 0 \\
\hline 3 & Cukup Puas & 4 & 13,33 \\
\hline 4 & Puas & 22 & 73,33 \\
\hline \multirow[t]{3}{*}{5} & Sangat Puas & 4 & 13,33 \\
\hline & Jumlah & 30 & 100 \\
\hline & Indeks & & $\%$ (Puas) \\
\hline
\end{tabular}

Sumber : Hasil Data Olahan Primer, 2020.

Berdasarkan tabel diatas mayoritas responden berada pada klasifikasi puas yakni dengan indeks sebesar $67,5 \%$. Level kepuasan ataupun ketidakpuasan dirasakan oleh responden yang sudah mengkonsumsi produk kerupuk kulit kakao. Sebaran responden berdasarkan kepuasan diketahui konsumen yang merasa sangat puas $13,33 \%$ dan yang merasa puas $73,33 \%$ tetapi $13,33 \%$ konsumen cukup merasa puas.

Hal ini disebabkan karena berdasarkan keadaan di lapangan tingkat kepuasan terhadap rasa, kemasan, harga yang dirasakan adalah puas. Dengan begitu kepuasan yang dirasakan responden setelah mengkonsumsi suatu produk akan mendorong untuk terjadinya pembelian ulang mungkin hingga sampai berlangganan.

\section{Loyalitas terhadap Produk}

Loyalitas produk diartikan sebagai sikap konsumen terhadap suatu produk, yang memiliki keinginan kuat untuk membeli ulang produk yang sama pada saat sekarng maupun masa yang akan datang (Sumarwan, 2004).

Berdasrkan hasil penelitian loyalitas dapat diklasifikasikan sebagai berikut: sangat setuju (5), setuju (4), netral (3), tidak setuju (2), dan sangat tidak setuju (1). Sebaran responden berdasarkan loyalitas terhadap produk dapat dilihat pada tabel berikut : Tabel 12. Respon Kosumen terhadap Loyalitas.

\begin{tabular}{crrr}
\hline No & Pernyataan & Jumlah & Persentase $\%$ \\
\hline 1 & Sangat Tidak Setuju & 0 & 0
\end{tabular}

\begin{tabular}{|c|c|c|c|}
\hline 2 & Tidak Setuju & 0 & 0 \\
\hline 3 & Netral & 4 & 13,33 \\
\hline 4 & Setuju & 24 & 80 \\
\hline \multirow[t]{3}{*}{5} & Sangat Setuju & 2 & 6,67 \\
\hline & Jumlah & 30 & 100 \\
\hline & Indeks & 68,0 & \\
\hline
\end{tabular}

Sumber : Hasil Data Olahan Primer, 2020.

Berdasarkan tabel diatas diketahui mayoritas responden berada pada klasifikasi setuju untuk melakukan pembelian pada produk kerupuk kulit kakao yakni dengan indek sebesar $68 \%$. Sebaran responden berdasarkan loyalitas terhadap produk kerupuk kulit kakao yaitu sebanyak $24(80 \%)$ orang setuju dan 2 $(6,67 \%)$ orang menjawab sangat setuju, sedangkan yang menjawab netral sebanyak $4(13,33 \%)$ orang. Bentuk keloyalitasan terhadap produk kerupuk kulit kakao adalah terjadinya pembelian ulang atau pembelian lebih dari satu kali pada produk dalam kurun waktu yang tidak dapat ditentukan. Mayoritas responden mulanya ingin mencoba namun nyatanya mereka kembali mengkonsumsi kerupuk kulit kakao yang sudah biasa dibeli sebelumnya.

\section{Analisis Faktor - Faktor yang Berhubungan dan pengaruh pada Respon Konsumen terhadap Produk Kerupuk Kulit Kakao}

Analisis kolerasi dilakukan untuk mengetahui hubungan antara dua variable bebas (X) atau lebih dengan variable terikat (Y). Sedangkan uji regresi linier dilakukan untuk meramalkan nilai pengaruh antara dua variable atau lebih terhadap variable terkait (untuk membuktikan ada tau tidaknya hubungan fungsional atau hubungan kausal antara variable bebas $\left(\mathrm{X}_{1}, \mathrm{X}_{2}\right.$ dan $\mathrm{X}_{3}$ atau lebih) dengan satu variable terkait (Y).

Hubungan antara variabel X (rasa, kemasan dan harga) dengan variabel Y (respon konsumen terhadap pembelian kerupuk kulit kakao) dianalisis dengan menggunakan statistika parametrik uji korelasi pearson product moment dengan rumus:

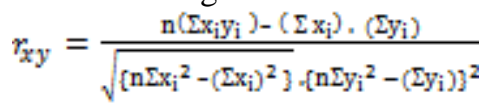

Hasil pengujian secara statistik terhadap faktorfaktor yang berhubungan dengan respon konsumen terhadap pembelian kerupuk kulit kakao yang dihitung dengan menggunakan SPSS 16 dapat dilihat pada tabel 13 .

Pengaruh antara variabel bebas yaitu rasa (X1), kemasan (X2) dan harga (X3) dengan respon konsumen $(\mathrm{Y})$ yang dilihat dari kepuasan dan loyalitas setelah membeli kerupuk kulit kakao dianalisis dengan menggunakan uji regresi berganda dengan Rumus :

$$
\hat{\mathrm{Y}}=a+b_{1} \cdot X_{1}+b_{2} \cdot X_{2} \times b_{\mathrm{a}} \times X_{\mathrm{a}}
$$

Hasil pengujian secara statistik pengaruh variabel bebas (rasa, kemasan dan harga) dengan variabel terikat (respon konsumen terhadap kerupuk kulit kakao) yang dihitung dengan menggunakan SPSS 16 dapat dilihat pada tabel 13 . 
Tabel 13. Hasil analisis korelasi variabel $\mathrm{X}$ (rasa, kemasn dan harga) terhadap variabel $\mathrm{Y}$ (respon Konsumen).

\begin{tabular}{lcccc}
\hline $\begin{array}{c}\text { Variabel } \\
(\mathbf{X})\end{array}$ & Variabel (Y) & r-hitung & sig & Hubungan \\
\hline Rasa & Respon & 0,631 & 0,00 & Kuat \\
Kemasan & Konsumen & 0,429 & 0,18 & Cukup Kuat \\
Harga & & 0,658 & 0,00 & Kuat \\
\hline$\alpha=0,5$ & & & & \\
\hline
\end{tabular}

Sumber : Hasil Data Olahan Primer, 2020.

Tabel 14. Hasil Analisis Regresi variabel X (rasa, kemasn dan harga) terhadap variabel $\mathrm{Y}$ (respon Konsumen).

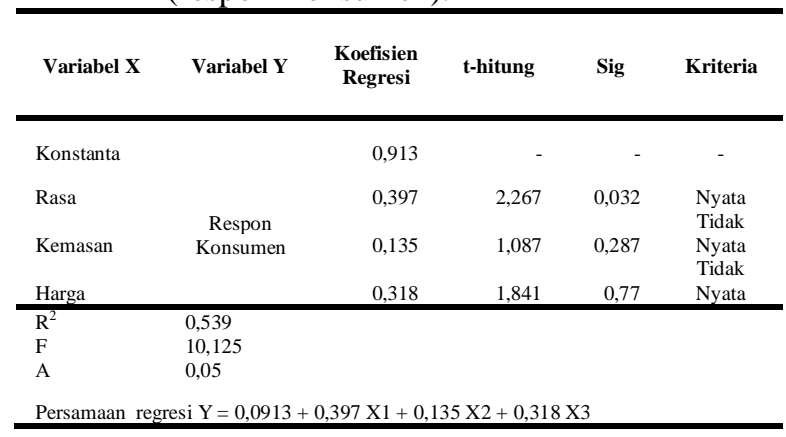

Sumber : Hasil Data Olahan Primer, 2020.

\section{Hasil Uji Kolerasi}

Uji kolerasi ini dilakukan untuk mengetahui hubungan antara variabel X (rasa, kemasan, dan harga) dengan variable Y (Respon Konsumen) di Desa Sido Makmur. Berdasarkan hasil uji kolerasi pada tabel 13, menunjukkan bahwa rasa, kemasan dan harga memiliki hubungan dengan respon konsumen terhadap Pembelian kerupuk kulit kakao di Desa Sido Makmur.

a) Variabel Rasa Kerupuk (X1)

Pada tabel 13, diketahui pada tingkat kepercayaan $95 \%(\alpha ; 0,05)$ variabel rasa pada kerupuk kulit kakao (X1) dengan respon konsumen terhadap pembelian (Y) mempunyai nilai $r$ hitung sebesar 0,631 dengan nilai signifikan 0,000 hal ini menunjukkan bahwa variabel rasa memiliki hubungan sebesar $63,1 \%$, artinya variabel $\mathrm{X}$ dengan variabel $\mathrm{Y}$ memiliki hubungan yang tergolong kuat terhadap pembelian kerupuk kulit kakao.

\section{b) Kemasan kerupuk (X2)}

Pada tingkat kepercayaan 95\% $(\alpha ; 0,05)$ variabel kemasan Kerupuk kulit kakao (X2) dengan respon konsumen terhadap pembelian kerupuk (Y) mempunyai nilai $r$ hitung sebesar 0,429 dengan nilai signifikan 0,018, hal ini menunjukkan bahwa variabel kemasan kerupuk memiliki hubungan sebesar 42,9\%, artinya variabel $\mathrm{X}$ dengan variabel $\mathrm{Y}$ memiliki hubungan yang tergolong cukup kuat dengan respon konsumen terhadap pembelian kerupuk kulit kakao (tabel 13).

\section{c) Harga Kerupuk (X3)}

Pada tingkat kepercayaan 95\% $(\alpha ; 0,05)$ variabel harga Kerupuk kulit kakao (X3) dengan respon konsumen terhadap pembelian kerupuk (Y) mempunyai nilai $r$ hitung sebesar 0,658 dengan nilai signifikan 0,000 hal ini menunjukkan bahwa variabel harga pada kerupuk kulit kakao memiliki hubungan sebesar 65,8\% dengan respon konsumen, artinya variabel $\mathrm{X}$ dengan $\mathrm{Y}$ memiliki hubungan yang tergolong kuat dengan respon konsumen terhadap pembelian kerupuk kulit kakao. (tabel 13)

\section{Hasil Analisis Regresi $\mathbf{R}^{2}$}

Ketetapan model ditunjukkan oleh koefisien determinasi yang telah disesuaikan atau adjusted $R$ square $\left(\mathrm{R}^{2}\right)$ dan biasanya dinyatakan dalam persen. Dari hasil analisis regresi diperoleh nilai koefisien determinasi $\mathrm{R}^{2}$ sebesar 0,539, artinya variable rasa (X1), kemasan (X2), dan harga(X3) berpengaruh dengan variabel respon konsumen (Y) terhadap pembelian kerupuk kulit kakao di Desa Sido Makmur Kecamatan Belitang sebesar 53,9\% sedangkan sisanya sebesar $46,1 \%$ dipengaruhi oleh variabel lain yang belum termasuk dalam penelitian misalnya usia dan jenis kelamin. (tabel 14).

\section{Hasil Uji F}

Berdasarkan hasil perhitungan statistic uji $\mathrm{F}$ yang telah dilakukan bahwa dalam penelitian tersebut diperoleh uji $\mathrm{F}$ sebesar 10,125 dengan tingkat kepercayaan 95\% $(\alpha=0,05)$. Dengan demikian maka $\mathrm{H}_{1}$ diterima dan $\mathrm{H}_{0}$ ditolak, yang berarti bahwa variabel bebas (rasa, kemasan, dan harga) yang diteliti secara bersama-sama berpengaruh nyata pada variable terkait (respon konsumen terhadap pembelian kerupuk kulit kakao di Desa Sido Makmur). (tabel 14).

\section{Hasil Uji t}

Uji $t$ adalah uji yang dilakukan untuk mengetahui pengaruh variabel bebas (rasa, kemasan dan harga) yang diteliti secara individual dengan variable terikat (respon konsumen terhadap pembelian kerupuk kulit kakao). Berdasarkan hasil uji t pada tabel 14, menunjukkan rasa, kemasan, dan harga berpengaruh pada respon konumen terhdap pembelian kerupuk kulit kakao di Desa Sido Makmur dengan persamaan $\mathrm{Y}=0,913+0,397 \mathrm{X}_{1}+0,135 \mathrm{X}_{2}+0,318$ $\mathrm{X}_{3}$.

\section{a. Rasa Kerupuk (X1)}

Nilai elasitas rasa terhadap respon konsumen untu membeli kerupuk kulit kakao adalah sebesar 0,397, artinya setiap penambahan rasa $1 \%$ akan meningkatkan respon konsumen untuk membeli sebesar 0,397\% dengan asumsi factor lain dianggap tetap.

Berdasarkan uji t pada tingkat kepercayaan $95 \%$ ( $\alpha$ : 0,05), Pada variabel Rasa Kerupuk kulit kakao (X1) dengan respon konsumen (Y) diperoleh nilai $\mathrm{t}$ sebesar 2,267 dengan nilai signifikan 0,032, artinya rasa berpengaruh nyata terhadap respon konsumen. Sehingga dengan menambah beberapa varian rasa skan memberikan pengaruh secara signifikan terhadap pembelian dengan faktor lain dianggap sama.

\section{b. Kemasan kerupuk (X2)}

Pada variabel kemasan kerupuk kulit kakao (X2) dengan respon konsumen (Y) memiliki nilai 
elasitas sebesar 0,135, yang berarti jika terjadi penambahan $1 \%$ kemasan akan meningkatkan respon konsumen sebesar $0,135 \%$ dengan asumsi faktor lain dianggap tetap.

Berdasarkan uji t pada tingkat kepercayaan $95 \%$ $(\alpha: 0,05)$. Variabel $\mathrm{X}$ dengan $\mathrm{Y}$ mempunyai nilai $\mathrm{t}$ sebesar 1,087 dengan nilai signifikan 0,287 hal ini menunjukkan bahwa variabel kemasan tidak berpengaruh nyata terhadap respon konsumen, sehingga dengan penambahan kemasan (bentuk lain) sebesar satu satuan tidak memberikan pengaruh secara signifikan terhadap respon konsumen.

\section{c. Harga Kerupuk (X3)}

Pada variabel harga Kerupuk kulit kakao (X3) dengan respon konsumen (Y) memiliki nilai elasitas sebesar 0,318 , yang berarti setiap penambahan harga sebesar $1 \%$ akan meningkatkan respon konsumen sebesar 0,318\% dengan faktor lain dianggap tetap.

Berdasarkan uji $\mathrm{t}$ pada tingkat kepercayaan $95 \% \%(\alpha: 0,05)$, maka diperoleh nilai t sebesar 0,658 dengan nilai signifikan 0,077 hal ini menunjukkan bahwa variabel harga kerupuk tidak berpengaruh nyata terhadap respon konsumen, sehingga setiap penambahan harga sebesar satu kesatuan tidak memberikan pengaruh secara signifikan terhadap respon konsumen dengan faktor lain dianggap tetap.

\section{V.KESIMPULAN DAN SARAN}

\section{A. Kesimpulan}

Berdasarkan hasil penelitian ini, maka kesimpulan yang dapat dimbil adalah sebagai berikut :

1. Potensi pendapatan yang diperoleh dari pengelolahan kerupuk kulit kakao di Desa Sido Makmur sebesar Rp 5.679.860 /bulan atau Rp 946.643 /PP.

2. Respon masyarakat terhdap pemhelolahan limbah kakao menjadi kerupuk adalah setuju dengan indeks $77,5 \%$ dan respon konsumen terhadap produk kerupuk kulit kakao dapat diklasifikasikan baik.

3. Baik secara bersama - sama maupun secara individu bahwa variabel rasa (X1), kemasan (X2), dan harga (X3) berpengaruh secara signifikan terhadap keputusan konsumen untuk membeli kerupuk kulit kakao.

\section{B. Saran}

Adapun saran berdasarkan penelitian yang telah dilaksanakan pada usaha pengelolahan kulit kakao menjadi kerupuk di Desa Sido Makmur Kecamatan Belitang Kabupaten OKU Timur adalah sebagai berikut :

1. Dalam pengelolahan kulit kakao menjadi kerupuk ini sebaiknya di lakukan dengan membentuk kelompok supaya tidak banyak kulit kakao yang terbuang dan pendapatan yang di peroleh pasti.

2. Diharapkan masyarakat tidak hanya setuju dalam usaha pengelolahan kulit kakao menjadi kerupuk tetapi masyarakat ikut serta untuk mengembangkan usaha pengelolahan keupuk kulit kakao.

3. Untuk tetap mempertahankan respon konsumen yang sudah baik, sebaiknya responden pengolahan kerupuk kulit kakao harus mampu untuk meningkatkan kualitas kerupuk kulit kakao dengan dengan menambah beberapa varian rasa dan packing dengan pelabelan merek produk yang sesuai dengan standar BP.POM.

4. Didaftarkan pada disperindang OKU Timur dan izin ketahanan pangan OKU Timur sehingga produk bisa dipasarkan di pasar moderen seperti mini market/super market.

\section{DAFTAR PUSTAKA}

Djatmiko, B., H. Suprapto, Sukardi dan S. Raharja. 1989. Studi Kelayakan Pemanfaatan Pod cacao Sebagai Bahan Baku Silase di PTP XXIII. Kerjasama PTP XXIII, Surabaya dengan Laboratorium PengawasanMutu Faleta IPB. Bogor.

Riduwan. 2011. Dasar - dasar Statistika. Alfabeta. Bandung.

Listyannisa, A., 2012, Isolasi Senyawa Antioksidan dari Kulit Buah Coklat (Theobroma cacao L.), Skripsi, Program Studi Farmasi, Fakultas Matematika dan Ilmu Pengetahuan Alam, Universitas Jenderal Achmad Yani, Cimahi.

Purnama, I.N., 2004. Kajian Potensi Isolat Kapang Pemecah Ikatan Tanin Pada Kulit Buah Kakao (Theobromti cacao L.), Skripsi, Program Studi Nutrisi dan Makanan Ternak, Departemmen Ilmu Nutrisi dan Makanan Ternak, Fakultas Peternakan, Institut Pertanian Bogor, Bogor.

Pusat Penelitian Kopi dan Kakao Indonesia, 2004. Panduan Lengkap Budidaya Kakao. PT. Agromedia Pustaka. Jakarta.

Sjarkowi. F dan Marwan, S.2010. manajemen Pengembangan Agribisnis. CV Baldad Grafiti Press. Palembang.

Soekartawi, 2003. Agribisnis Teori dan Aplikasinya. PT. raja Grafindo Persada. Jakarta. 